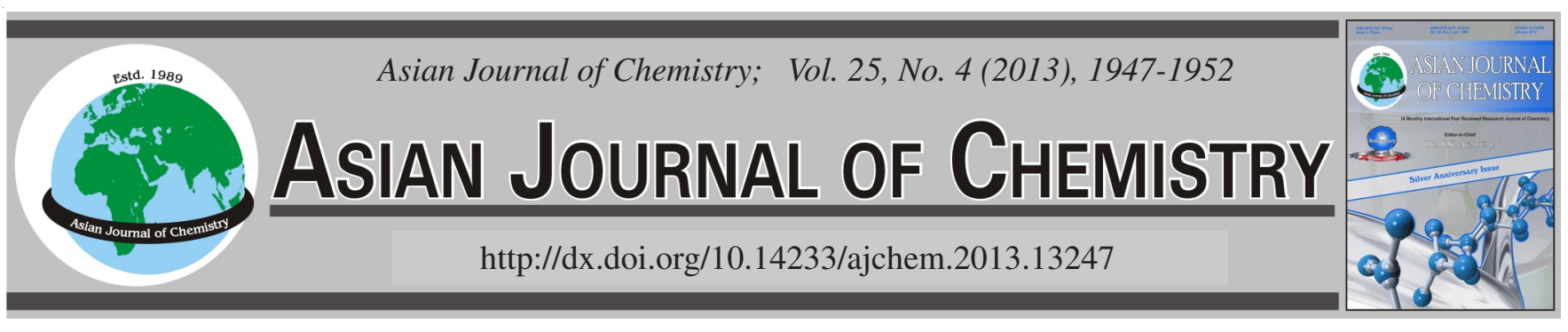

\title{
Thermal and Mechanical Properties of Walnut Shell and Glass Fiber Reinforced Thermoset Polyester Composites
}

\section{Ayhan Onat ${ }^{1}$, S. Serdar Pazarlioglu ${ }^{2}$, Erhan Sancak ${ }^{3, *}$, Sezgin Ersoy ${ }^{4}$, Ali Beyit $^{3}$ and Ramazan Erdem ${ }^{5}$}

\begin{abstract}
${ }^{1}$ Department of Mechanical Education, Technical Education Faculty, Marmara University, Istanbul, Turkey ${ }^{2}$ Department of Metallurgy Education, Technical Education Faculty, Marmara University, Istanbul, Turkey ${ }^{3}$ Department of Textile Education, Technical Education Faculty, Marmara University, Istanbul, Turkey ${ }^{4}$ Department of Mechatronic Education, Technical Education Faculty, Marmara University, Istanbul, Turkey ${ }^{5}$ Marmara University Institute of Pure and Applied Sciences, Goztepe, Istanbul 34722, Turkey
\end{abstract}

*Corresponding author: E-mail: esancak@marmara.edu.tr

\begin{abstract}
Recent studies have shown that focusing on industrial waste materials will enable us to recover the economical values. In line with the objective of present study, walnut shell is a waste material was selected to ensure economic recovery. Furthermore, biaxial fiber glass based fabrics were used in order to improve the mechanical properties of the composite materials to be produced. Thermosetting polyester resin was used as matrix material in producing composite materials. Nine different composite materials were produced as a result of addition of walnut shells at different sizes and ratios. Mechanical tests and thermal conductivity tests of these composite materials were carried out and the results were assessed.
\end{abstract}

Key Words: Bi-axial knitted fabrics, Composite materials, Walnut's shell, Polyester composites.

\section{INTRODUCTION}

Fiber and textile surface reinforced composite materials are widely used in a broad range of usage fields. Defence industry, space industry, automotive industry, sea transport industry and sport materials are exemplary fields where composite materials are widely used. The reason for preference of these materials in the aforementioned fields is that they have a high resistance and a certain level of hardness. They become attractive in such fields owing to their high resistance, design flexibility and low weight. These properties of composite materials are associated with the properties of the materials that they contain ${ }^{1}$.

In recent years, a special concern has been manifested towards green composites. Some of the effort has been based on the use of new waste sources, with the aim to obtain biologically active compounds that can be applied in different fields and applications. These natural lignocellulosic cereal residues (by-product) are compatible with the environment and could provide the sources for specialty chemicals. Cereal waste or agro waste product is an annually renewable fiber and is available in abundant volume throughout the world. The composite industries are looking into alternative low cost lignocellulosic sources, which can decrease overall manufacturing costs and increase properties of the materials. Agro husk raw material could be a potential alternative replacing wood for making composites material particularly for automobile, packaging and construction applications. In previous years, cereal lignocellulosic raw material (straw, cornstalk, bagasse) has been used for making composites with polypropylene, polyethylene, polyester, polyvinyl acetate, polyurethane, poly (3-hydroxybutyrate-co-3- hydroxyvalearate), polylactic acid and Novolac resin. Apart from composite materials, the particle boards from agro by-product could be another potential alternative $^{2}$.

Walnut is the stone or the ridged or corrugated seed of a deciduous tree of the genus Juglans, having pinnately compounded leaves. The nuts are usually enclosed in a leathery or woody hull. Pistachios are the fruit of Pistachio Vera tree ${ }^{3}$. The world production of walnut and pistachios in 2008 was estimated 2.016.995 metric tons and 548.377 metric tons, respectively. 170.897 metric tons walnut and 120.113 metric tons pistachios are produced in Turkey ${ }^{4}$.

Over the past two decades plant fibers have been receiving considerable attention as substitute for synthetic fiber reinforcements such as glass in plastics. The advantages of plant fibers are low cost, low density, acceptable specific strength, good thermal insulation properties, reduced tool wear, reduced dermal and respiratory irritation, renewable resource and recycling possible without affecting the environment. Some 
of the plant fiber based thermoplastic composites have already found applications in furniture, packaging, building and automobile industries 5 .

Polymer waste is disposed in large landfills causing serious problems on the environment, while biodegradable materials are envisaged to be an excellent alternative to tackle this problem, by reducing the waste volume. Hence, for these reasons it has not been surprising that the use of cellulosic materials in the production of composites has gained significant importance $^{6}$.

Multi axial non-crimp fabric is a relatively new class of textile performs for polymer composites that consist of multiple layers of fibrous yarns stitched together by warp knitting. The most commonly used types of non-crimp fabrics are biaxial, triaxial and quad axial fabrics in which straight, uncrimped yarns are aligned in the warp $\left(0^{\circ}\right)$, bias $\left(30^{\circ}<\theta<\right.$ $\left.90^{\circ}\right)$ and/or weft $\left(90^{\circ}\right)$ directions to provide multidirectional in-plane properties. In addition, chopped fiber or fleece mat can be incorporated into the fabric, although their use is usually confined to the surface layer to provide a high quality finish to a composite product. The yarn layers and mats are bound together by warp knitting with a chain or tricot stitch pattern using polyester thread or (less often) aramid or glass yarn ${ }^{7,8}$. Glass fibers are used to improve mechanical properties of composites fibrous reinforcement materials are used glass fiber. It is known that glass fiber reinforced polymer matrix composites have good mechanical properties. And fiber reinforced composites are the main group over all composites ${ }^{9,10}$.

The combination of stacked fiber layers into a single, thick fabric overcomes the high cost and long production time often incurred with the manual hand lying of thick performs using conventional single layer fabric and tape. A further advantage is that composites reinforced with non-crimp fabric generally exhibit higher in-plane mechanical properties than conventional woven fabric composites because the yarns are not crimped. In addition, the interlaminar shear resistance, delamination toughness and impact damage tolerance of non-crimp fabric composites is superior to conventional tape laminates because of the through-thickness reinforcement provided by the stitches ${ }^{11-13}$.

\section{EXPERIMENTAL}

Multi axial non-crimp fabrics: The extension properties of a variety of biaxial non-crimp fabrics consisting of continuous E-glass yarns stitched together with $0.14 \mathrm{~mm}$ diameter polyester thread were evaluated. Biaxial fabrics manufactured by Metyx (Turkey) using a Liba multi axial warp-knitting machine were studied (Table-1).

Waste materials: In present study, natural waste material walnut shell and pistachios shell were used to produce composite structure. Walnut shell and pistachios shell broke into

TABLE-1

SPECIFICATIONS OF BIAXIAL NON-CRIMP FABRICS

\begin{tabular}{lccc}
\hline Sample type & Description & $\begin{array}{c}\text { Orientation } \\
\text { of tows }\left(^{\circ}\right)\end{array}$ & $\begin{array}{c}\text { Total weight } \\
\left(\mathrm{g} / \mathrm{m}^{2}\right)\end{array}$ \\
\hline Biaxial non-crimp fabrics & E-glass & $0^{0}, 90^{0}$ & 700 \\
E-glass mat & E- glass & - & 300 \\
\hline
\end{tabular}

pieces of three kinds of size by centrifuge machine as seen in Fig. 2 (c). Then 18 different kinds of composites were produced with them.

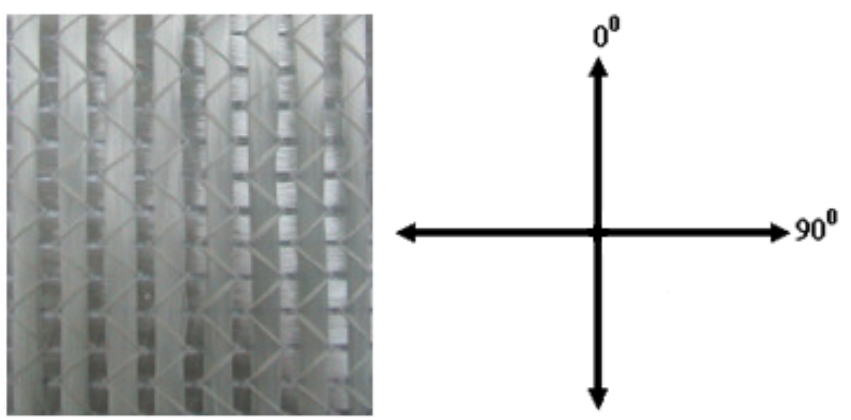

Fig. 1. Picture of biaxial non-crimp fabrics
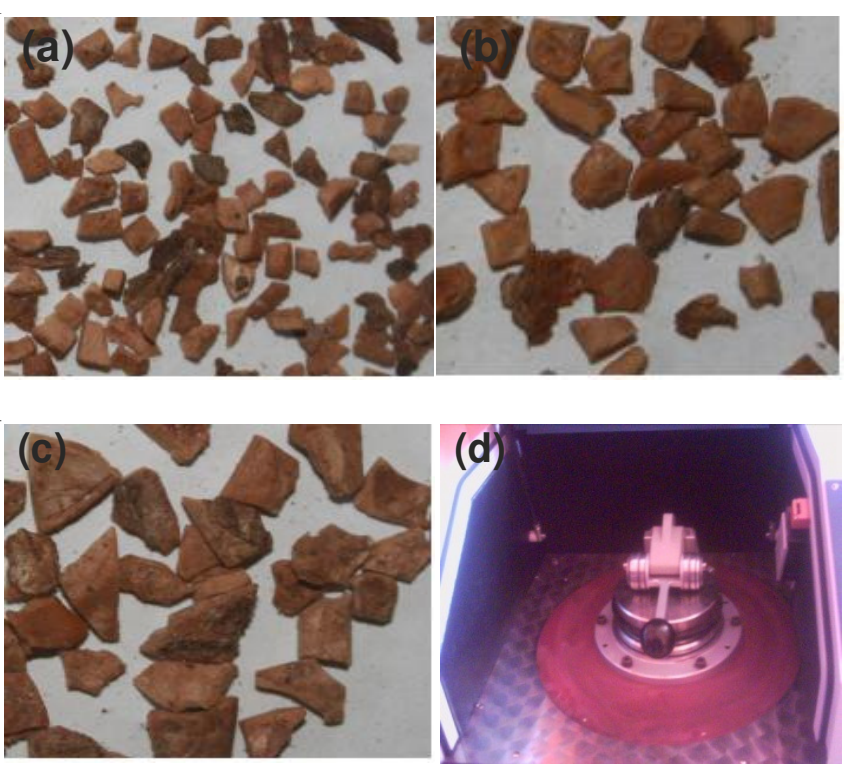

Fig. 2. (a) Walnut shell (12 mesh); (b) Walnut shell (8 mesh); (c) Walnut shell (4 mesh); and (d) Centrifuge machine

Manufacturing of composite structures: Matrix resin is thermoset polyester (Polipol 351) manufactured by Poliya (Turkey) were used to fabricate composite structures. Thermoset polyester resin was chosen to fabricate composite because of its low price.

Thermosetting polyester was applied as a resin. There are several major manufacturing methods in fiber-reinforced polymer industry. Composite structures were fabricated by hand Lay up method. Stacking of the plies was continued until a certain thickness was obtained. After lamination procedure, composites were cured at room temperature under the settled pressure for $24 \mathrm{~h}$. Properties of reinforced composites are given in Table-2.

Mechanical property characterization: Tensile test technique, ASTM D3039/ 3039M-07 was used to determine the tensile strength of the composite laminates. The specimens were tested using Devotrans universal test machine at a crosshead speed of $10 \mathrm{~mm} / \mathrm{min}$. At least five specimens for each composition were tested. Impact strength was checked by means of CHEAST charpy impact resistance based on ISO 179-1 standard. The results of mechanical properties are given in Table-2. 
TABLE-2

PROPERTIES OF COMPOSITE STRUCTURES

\begin{tabular}{|c|c|c|c|c|c|c|c|}
\hline $\begin{array}{l}\text { Sample } \\
\text { code }\end{array}$ & Structure of composition & $\begin{array}{l}\text { Thickness } \\
(\mathrm{mm})\end{array}$ & $\begin{array}{l}\text { Total weight } \\
\left(\mathrm{g} / \mathrm{m}^{2}\right)\end{array}$ & $\begin{array}{l}\text { Particle size } \\
\text { (mesh) }\end{array}$ & \multicolumn{3}{|c|}{$\begin{array}{c}\text { Fabric/resin/walnut } \\
\text { cell }(\%)\end{array}$} \\
\hline SAMPLE 1 & 1 Layer mat/1layer fabrics /walnut shell/ 1 layer fabrics/1 layer mat & 7.2 & 8800 & 12 & 22 & 63 & 15 \\
\hline SAMPLE 2 & 1 Layer mat/1layer fabrics /walnut shell/ 1 layer fabrics/1 layer mat & 8.5 & 10080 & 12 & 20 & 55 & 25 \\
\hline SAMPLE 3 & 1 Layer mat/1layer fabrics /walnut shell/ 1 layer fabrics/1 layer mat & 9.5 & 11360 & 12 & 18 & 47 & 35 \\
\hline SAMPLE 4 & 1 Layer mat/1layer fabrics /walnut shell/ 1 layer fabrics/1 layer mat & 7.2 & 8800 & 8 & 22 & 63 & 15 \\
\hline SAMPLE 5 & 1 Layer mat/1layer fabrics /walnut shell/ 1 layer fabrics/1 layer mat & 8.5 & 10080 & 8 & 20 & 55 & 25 \\
\hline SAMPLE 6 & 1 Layer mat/1layer fabrics /walnut shell/ 1 layer fabrics/1 layer mat & 9.5 & 11360 & 8 & 18 & 47 & 35 \\
\hline SAMPLE 7 & 1 Layer mat/1layer fabrics /walnut shell/ 1 layer fabrics/1 layer mat & 7.2 & 8800 & 4 & 22 & 63 & 15 \\
\hline SAMPLE 8 & 1 Layer mat/1layer fabrics /walnut shell/ 1 layer fabrics/1 layer mat & 8.5 & 10080 & 4 & 20 & 55 & 25 \\
\hline SAMPLE 9 & 1 Layer mat/1layer fabrics /walnut shell/ 1 layer fabrics/1 layer mat & 9.4 & 11360 & 4 & 18 & 47 & 35 \\
\hline
\end{tabular}

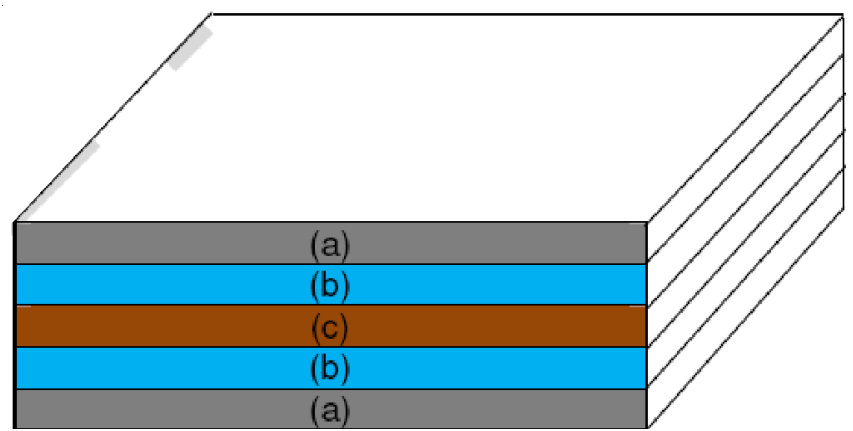

Fig. 3. Cross section of composite (a) E-glass mat (b) Bi-axial fabric (c) walnut cell

Heat conduction test (conduction method): When there is a temperature difference between a system and another system, energy transferred from a system margin due to only one temperature difference is called as heat. Heat conduction is an energy flow-taking place through direct contact or kinetic movements of molecules in static liquids and through contact of molecules or movements of electrons from high energy level (from temperature) to low energy level in solids. Thus, metals display good heat and electric conductivity ${ }^{14}$.

Heat conduction equation is based on empirical researches conducted by Fourier. The Fourier's law:

$$
\begin{gathered}
\mathrm{Q}_{\mathrm{x}}=-\mathrm{kA} \frac{\mathrm{dT}}{\mathrm{dx}} \\
\frac{\mathrm{dT}}{\mathrm{dx}}=\lim \Delta \mathrm{x} \rightarrow 0 \frac{\Delta \mathrm{T}}{\Delta \mathrm{x}} \\
\mathrm{Q}_{\mathrm{x}}=-\mathrm{k} \times \mathrm{A} \frac{\mathrm{dT}}{\mathrm{dx}} \\
\mathrm{Q}_{\mathrm{x}}=-\mathrm{k} \times \mathrm{a} \times \frac{\mathrm{T}_{2}-\mathrm{T}_{1}}{\mathrm{X}_{2}-\mathrm{X}_{1}}=\mathrm{k} \times \mathrm{A} \times \frac{\mathrm{T}_{1}-\mathrm{T}_{2}}{\mathrm{X}_{2}-\mathrm{X}_{1}} \\
\mathrm{Q}_{\mathrm{x}}=\mathrm{k} \times \mathrm{A} \times \frac{\Delta \mathrm{T}}{\mathrm{L}}
\end{gathered}
$$

Heat conduction tests of composite materials were conducted by using P.A. HILTON LTD. H940 heat conduction unit. Linear conduction module was used in the heat conduction device. Heat flow value was detected as watt $(\mathrm{Q})$ on the digital screen of the device. Thickness of the test composite materials, area of the test surface and temperature difference were found and placed in the following formula:

$$
\mathrm{K}=\frac{\mathrm{Q} \times \mathrm{dx}}{\mathrm{A} \times \Delta \mathrm{T}}
$$

As a result of the process, heat conduction coefficient (K) was found in $w / \mathrm{m}^{\circ} \mathrm{C}$.

\section{RESULTS AND DISCUSSION}

Mechanical properties: Mechanical test results of the composite materials are displayed in Table-3. Mechanical tests

\begin{tabular}{|c|c|c|c|c|c|}
\hline \multicolumn{6}{|c|}{$\begin{array}{c}\text { TABLE-3 } \\
\text { MECHANICAL AND THERMA }\end{array}$} \\
\hline $\begin{array}{l}\text { Sample } \\
\text { code }\end{array}$ & $\begin{array}{c}\text { Test } \\
\text { direction }\end{array}$ & $\begin{array}{c}\text { Tensile } \\
\text { strength } \\
(\mathrm{MPa})\end{array}$ & $\begin{array}{c}\text { Impact } \\
\text { strength } \\
\left(\mathrm{KgJ} / \mathrm{mm}^{2}\right)\end{array}$ & $\begin{array}{l}\text { Flexture } \\
(\mathrm{MPa})\end{array}$ & $\begin{array}{c}\text { Heat } \\
\text { conduction } \\
(\mathrm{W} / \mathrm{mC})\end{array}$ \\
\hline \multirow{2}{*}{$\underset{1}{\text { Sample }}$} & 0 & 15251 & 80.64 & 231.0 & \multirow{2}{*}{2.89} \\
\hline & 90 & 15181 & 77.55 & 218.1 & \\
\hline \multirow{2}{*}{$\begin{array}{l}\text { Sample } \\
2\end{array}$} & 0 & 14032 & 66.40 & 215.9 & \multirow{2}{*}{2.92} \\
\hline & 90 & 13986 & 66.00 & 186.3 & \\
\hline \multirow{2}{*}{$\begin{array}{c}\text { Sample } \\
3\end{array}$} & 0 & 13847 & 63.22 & 193.1 & \multirow{2}{*}{3.23} \\
\hline & 90 & 13813 & 61.00 & 145.6 & \\
\hline \multirow{2}{*}{$\begin{array}{c}\text { Sample } \\
4\end{array}$} & 0 & 14231 & 75.75 & 224.6 & \multirow{2}{*}{2.94} \\
\hline & 90 & 14127 & 66.10 & 201.3 & \\
\hline \multirow{2}{*}{ Sample } & 0 & 13833 & 66.17 & 209.2 & \multirow{2}{*}{3.11} \\
\hline & 90 & 13211 & 54.16 & 173.0 & \\
\hline \multirow{2}{*}{ Sample } & 0 & 12806 & 60.70 & 183.6 & \multirow{2}{*}{3.56} \\
\hline & 90 & 12621 & 47.62 & 142.0 & \\
\hline \multirow{2}{*}{$\begin{array}{l}\text { Sample } \\
7\end{array}$} & 0 & 14121 & 75.47 & 218.1 & \multirow{2}{*}{2.99} \\
\hline & 90 & 14021 & 52.68 & 196.8 & \\
\hline \multirow{2}{*}{$\begin{array}{l}\text { Sample } \\
8\end{array}$} & 0 & 13014 & 63.80 & 165.2 & \multirow{2}{*}{3.47} \\
\hline & 90 & 12935 & 50.57 & 143.0 & \\
\hline \multirow{2}{*}{$\begin{array}{c}\text { Sample } \\
9\end{array}$} & 0 & 12535 & 51.80 & 151.4 & \multirow{2}{*}{3.70} \\
\hline & 90 & 10931 & 46.56 & 132.8 & \\
\hline
\end{tabular}
were conducted for each sample in 0 and 90 degree directions and experiments were repeated as specified in the standards. Resistance tests, three-point flexural and impact strength tests were applied to the composite materials. Results of the mechanical tests were compared in the graphics.

The results of the resistance of the composite materials were in Figs. 4-6. When graphics are examined, resistance values obtained in $0^{\circ}$ are higher than those obtained in $90^{\circ}$ degree. Resistance value difference between the angle directions results from orientation of glass fiber used in glass fabric used in the production of composite materials. It is higher in $90^{\circ}$ as glass fiber intensity in the fabric is higher at this angle direction. When Fig. 4 is examined, it is observed that sample 1 displays higher resistance than sample 4 and sample 7. Fig. 5 indicates that sample 2 displays higher resistance than sample 5 and sample 8. When Fig. 6 is analyzed, it is apparent that sample 3 displays higher resistance when compared to sample 
6 and sample 9. As size of the walnut shell used as waste material in the production of composite materials grows, resistance values of composite materials decrease. Figs. 4-6 demonstrate the resistance results of composite materials produced through addition of walnut shell at three different amounts. When Figs. 4-6 are examined individually, it is seen that resistance values decrease as the size of added walnut shell grows in all of three different amounts.

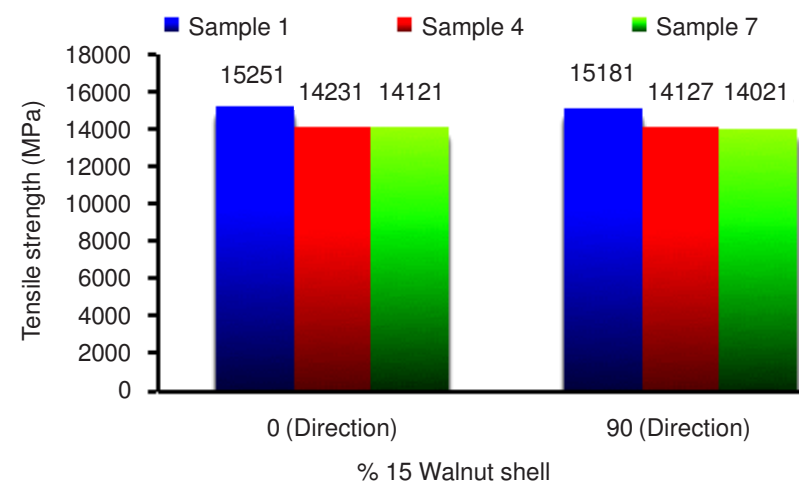

Fig. 4. Resistance results of composite materials containing $15 \%$ walnut shell

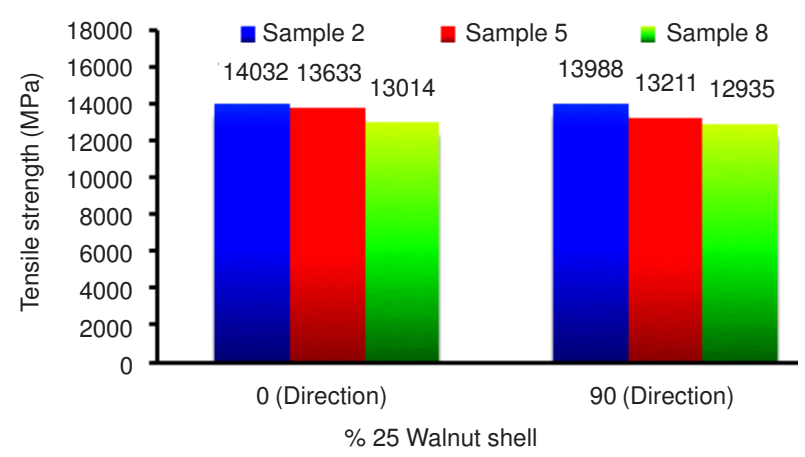

Fig. 5. Resistance results of composite materials containing $25 \%$ walnut shell

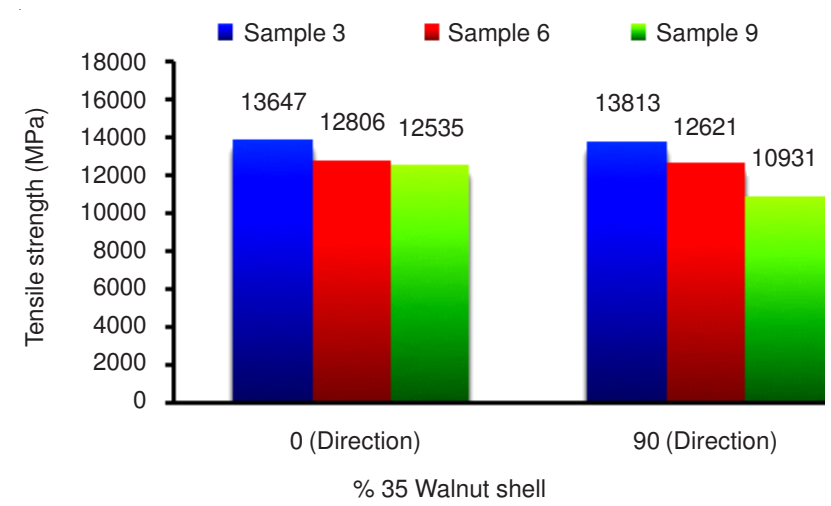

Fig. 6. Resistance results of composite materials containing $35 \%$ walnut shell

Three point flexure results of composite materials were evaluated in Figs. 7-9. When graphics are examined, it is observed that three-point flexure values obtained in $0^{\circ}$ are higher than those obtained in $90^{\circ}$. Three-point flexure value difference observed between the angle directions results from orientation of glass fiber used in glass fabric used in the production of composite materials. It is higher as glass fiber intensity used in the fabric in $90^{\circ}$ is higher. When Fig. 7 is examined, it is observed that sample 1 displays higher threepoint flexure than sample 4 and sample 7 . Fig. 8 indicates that sample 2 displays higher three-point flexure than sample 5 and sample 8. When Fig. 9 is analyzed, it is apparent that sample 3 displays higher three-point flexure when compared to sample 6 and sample 9. As size of the walnut shell used as waste material in the production of composite materials grows, three-point flexure values of composite materials fall. Figs. 7-9 contain the three point flexure results of composite materials produced through addition of walnut shell at three different amounts. When Figs. 7-9 are examined individually, it is seen that three-point flexure values decrease as the size of added walnut shell grows in all of three different amounts.

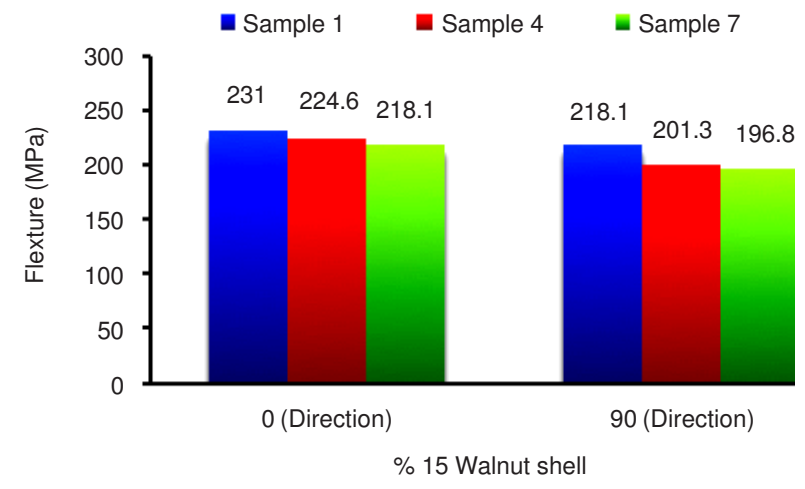

Fig. 7. Three point flexure results of composite materials containing $15 \%$ walnut shell

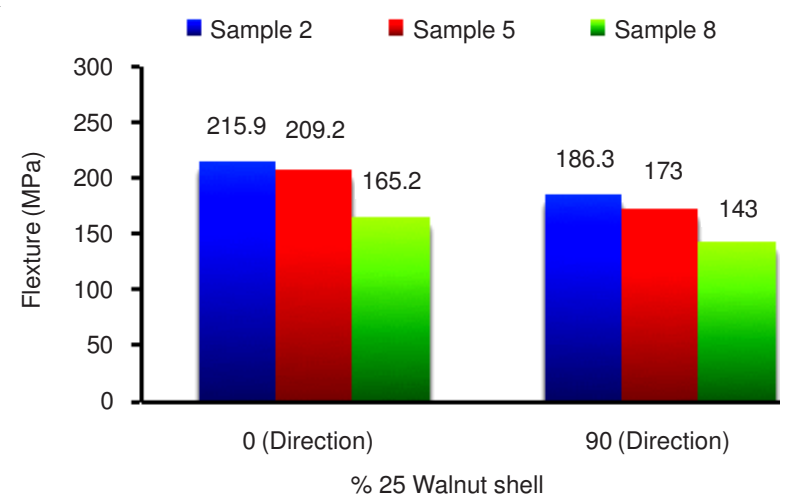

Fig. 8. Three point flexure results of composite materials containing $25 \%$ walnut shell

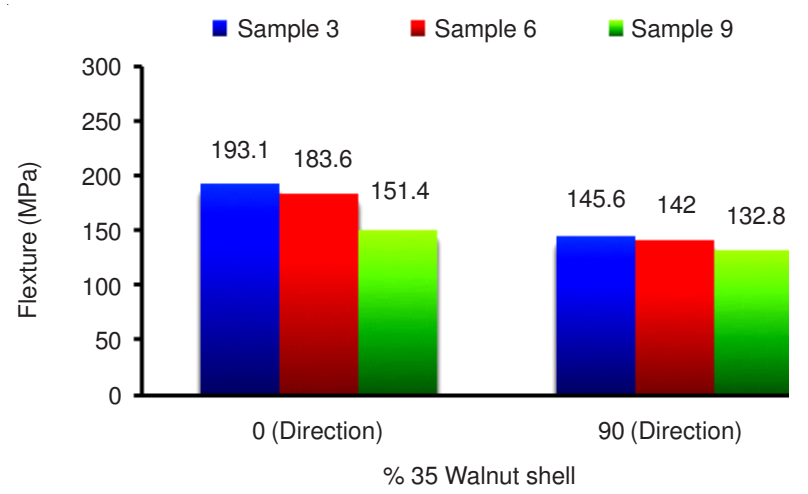

Fig. 9. Three point flexure results of composite materials containing $35 \%$ walnut shell

Impact strength results of composite materials are compared and evaluated in Figs. 10-12. When graphics are examined, it 
is observed values obtained in $0^{\circ}$ are higher than those obtained in $90^{\circ}$. Difference of impact strength values observed between the angle directions results from orientation of glass fiber used in glass fabric used in the production of composite materials. It is higher as glass fiber intensity used in the fabric in $90^{\circ}$ is higher. When Fig. 10 is examined, it is observed that sample 1 displays higher impact strength than sample 4 and sample 7. Fig. 11 indicates that sample 2 displays higher impact strength than sample 5 and sample 8 . When Fig. 12 is analyzed, it is apparent that sample 3 displays higher impact strength when compared to sample 6 and sample 9. As size of the walnut shell used as waste material in the production of composite materials grows, impact strength values of composite materials fall. Figs. 10-12 contain the impact strength results of composite materials produced through addition of walnut shell at three different amounts. When Figs. 10-12 are examined individually, it is seen that impact strength values decrease as the size of added walnut shell grows in all of three different amounts.

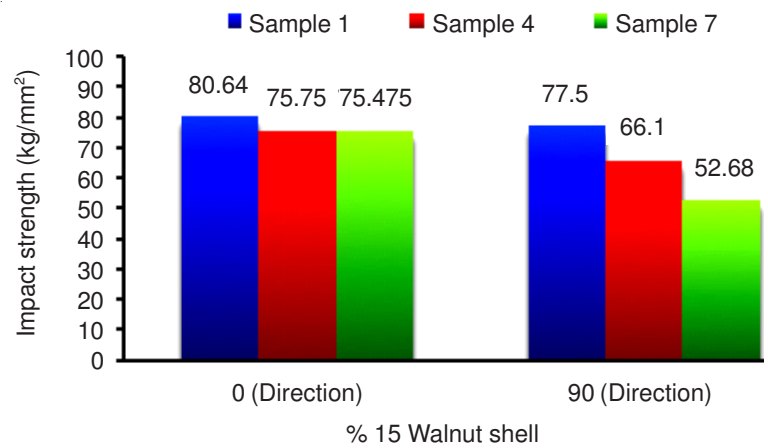

Fig. 10. Impact strength results of composite materials containing $15 \%$ walnut shell

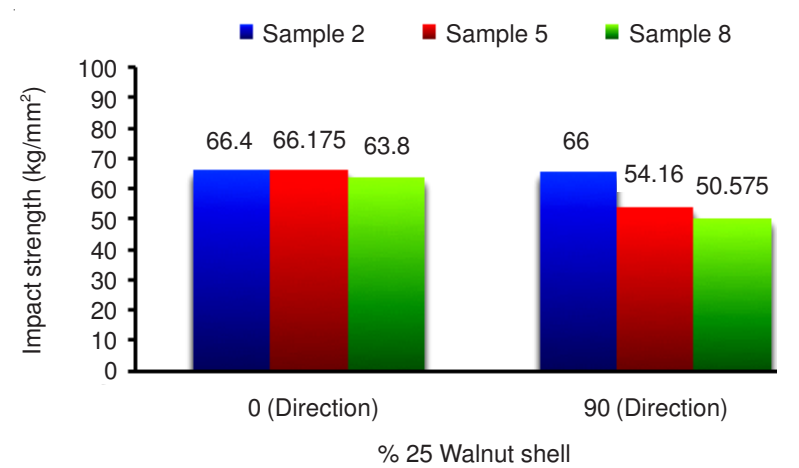

Fig. 11. Impact strength results of composite materials containing $25 \%$ walnut shell

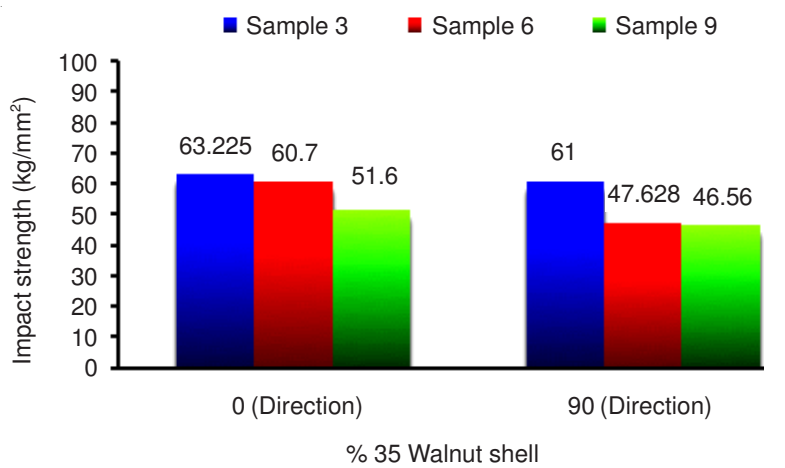

Fig. 12. Impact strength results of composite materials containing $35 \%$ walnut shell
Thermal conductivity properties: When graphic in the Fig. 13 is examined, comparison of DT heat conduction coefficients that the composite materials displayed is seen. Change of DT heat conduction coefficients of composite materials that were produced at different walnut shell addition ratios of 15 , 25 and $35 \%$ is evaluated individually. Three different walnut shell sizes are available for each addition ratio. Graphic indicates that as the size of walnut shell grows in the composite materials containing walnut shells at different ratios, DT heat conduction coefficient value also increases. A high DT heat conduction coefficient means that this material has a good heat conductivity property.

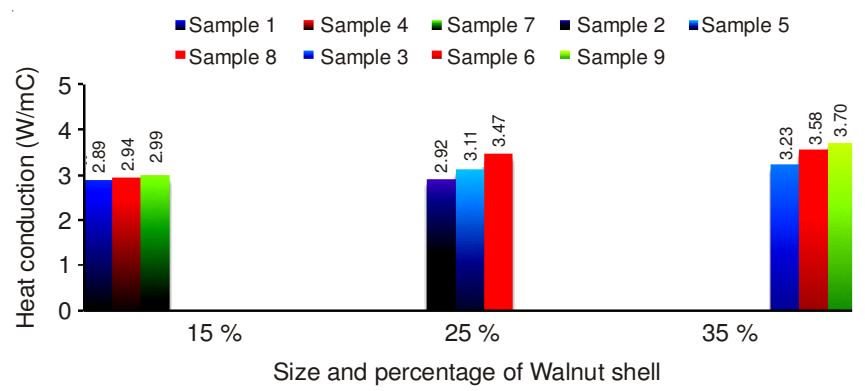

Fig. 13. Thermal conductivity results of composite materials

\section{Conclusion}

In this study, tests demonstrated that glass fiber based warp knitting and walnut shell reinforcements have impacts on mechanical and thermal properties of composite materials. Tests were applied to composite materials in $0^{\circ}$ and $90^{\circ}$ directions. Results of all mechanical tests are higher in $0^{\circ}$ when compared to the results obtained in $90^{\circ}$ direction. This difference of values results from different properties of fiber bundles forming the glass based biaxial fabric used in the production. Difference emerging between $0^{\circ}$ and $90^{\circ}$ directions as a result of these orientation properties is attributed to the biaxial glass based fabric. According to the results obtained from mechanical tests, a decrease in the particle size of the walnut shell used in the production of composite material yields better results. When the particle size is small, a better interface forms between matrix material and resin and, in turn, higher mechanical values are obtained. When heat conductivity results of composite materials are examined, it is observed that a higher heat conduction coefficient DT is obtained, as the particle gets bigger. It is understood from these results that when bigger walnut shells are used, produced composite materials isolate the heat more effectively. This better heat isolation can be attributed to the fact that more big walnut shell is found per unit area than small walnut shell as a result of the growth in particle size. In line with the results of this study, use of walnut shell that is a waste material in the composite materials in small particle sizes will make a positive contribution to mechanical strength. Use of big walnut shells yield better results in the fields of application where thermal isolation is sought.

\section{REFERENCES}

1. E. Bozkurt, E. Kaya and M. Tanoglu, Comp. Sci. Technol., 67, 3394 (2007).

2. A.K. Bledzki, A.A. Mamun and J. Volk, Comp. Sci. Technol., 70, 840 (2010). 
3. Debgiri Agro Products Ltd. Data Sheet, India, http://www. agriculturalproductsindia.com (2011).

4. World Production Data Sheet, Foreign Agricultural Service. United States department of Agriculture, USA. http://www.fas.usda.gov (2011).

5. M. Brahmakumar, C. Pavithran and R.M. Pillai, Comp. Sci. Technol., 65, 563 (2005)

6. A.K. Bledzki and J. Gassan, Prog. Polym. Sci., 24, 221 (1999).

7. G.A. Bibo, P.J. Hogg and M. Kemp, Comp. Sci. Technol., 57, 1221 (1997).

8. E. Bozkurt, E. Kaya and M. Tanoglu, Comp. Sci. Technol., 67, 3394 (2007).

9. D. Koçak, I. Mistik, M. Yüksek, E. Sancak and M. Akalin, Investigation of Thermal Properties of Multiaxial Glass and Carbon Fiber Reinforced
Polyester Composites, 5th International Istanbul Textile Conference, pp. 46, 19-21 May 2005, Istanbul, Turkey.

10. D. Koçak, I. Mistik, M. Yüksek, E. Sancak and M. Akalin, Thermal Properties of Multiaxial Glass Fiber Reinforced Polyester Resin Composites, 5th International Istanbul Textile Conference, pp. 47, 19-21 May 2005, Istanbul, Turkey.

11. M.T. Mathew, Naveen V. Padaki, L.A. Rocha, J.R. Gomes, R. Alagirusamy, B.L. Deopura and R. Fangueiro, Wear, 263, 930 (2007).

12. H. Kong, A.P. Mouritz and R. Paton, Comp. Struct., 66, 249 (2004).

13. G. Wu Du and F. Ko, Comp. Sci. Technol., 56, 253 (1996).

14. A.K. Dagsöz, Isi Geçisi ve Transferi, Beta Basim Yayim Dagitim A.S., Istanbul (1995) (In Turkish). 